\title{
Slik kan du møte mennesker i krise
}

Sykepleiere møter ofte mennesker i krise. Hva sier du til mannen som har fått beskjed om at han snart skal dø, eller til jenta som brått har mistet sin mor?

\section{Forfattere}

\section{Stina Fallsen}

sykepleier

Lungemedisinsk sengepost, UNN Troms $\varnothing$

\section{Nøkkelord}

Krise Traume Alvorlige hendelser Dødelig syk

Sykepleien 2017 105(9)(34-37)

DOI: https://doi.org/10.4220/Sykepleiens.2017.63735

HOVEDBUDSKAP

Medmenneskelighet trekkes frem som sentralt i møte med mennesker i krise. Hva gjør du når det ikke er noe å gjøre, og når ord blir fattige? Som sykepleier må du akseptere at du av og til ikke kan gjøre noe, og stole på at det faktisk er nok bare å være der.

Med denne artikkelen ønsker jeg å sette søkelyset på hvordan vi som sykepleiere møter mennesker i krise. På sykepleierstudiet lærer vi at det er viktig med god kommunikasjon. Det å vise respekt, gi omsorg og være medmennesker er i fokus. 
En ting jeg har savnet både på grunnutdanningen og videreutdanningen, er konkrete og håndfaste

eksempler på hva vi kan si, og hvordan vi skal opptre ovenfor mennesker i krise. Jeg skal derfor ved hjelp av faglitteratur og egne erfaringer som sykepleier forsøke å gjøre nettopp det.

Jeg jobber som sykepleier på en medisinsk sengepost, og der møter jeg mennesker i krise hver dag. Mennesker som har fått beskjed om uhelbredelig kreft - at det ikke finnes noen behandling. Jeg møter dem som har mistet sin aller kjæreste brått, og jeg treffer dem som har sittet ved sykehussengen dag ut og dag inn og sett døden komme sakte.

\section{Hva skal vi si?}

Som sykepleiere har vi nok kjent på det å bli overveldet, rørt og lammet av maktesløshet i møte med mennesker i krise. Handlingstrangen melder seg, vi vil så gjerne gjøre eller si noe som kan hjelpe.

Det er kanskje ikke så rart siden vi er drillet i å iverksette tiltak, evaluere og sette i gang nye tiltak hvis vi ikke oppnår ønsket resultat. Vi er løsningsorienterte og effektive, men hva gjør vi når vi ikke kan gjøre noe, og når ord blir fattige?

Jeg kjenner ofte på maktesløsheten og redselen for å si eller gjøre noe som kan forverre situasjonen. Akkurat hva vi skal si, er ofte en problemstilling blant mine kollegaer. For hva sier vi egentlig til en som har fått beskjed om at han snart skal dø, eller til en som har mistet en av sine nærmeste?

\section{Hva er en krise?}


En krise er en hendelse som innebærer en avgjørende kursendring i livet, som kommer i hvert menneskes liv (4). Livskriser anses for å være en naturlig del av menneskets livssyklus (6). Krisene er ikke like omfattende og dyptgripende for alle, men de inntreffer. Noen ganger er de av en slik karakter at livet ikke kan leves som det ble gjort før $(2,4)$.

\section{三 «Livskriser anses for å være en naturlig del av menneskets livssyklus.»}

En krise er ikke noe man bare kan kvitte seg med, den er en del av livet som mennesker må gjennom (1), og det er her vi som sykepleiere kommer inn. Som nyutdannet sykepleier var jeg en gang til stede idet en ung mann fikk beskjed om at han hadde kreft med spredning; det var for sent. Han var stille.

Etter en stund brøt han ut: «Jeg har jo spart og skal bygge meg hytte! Hva skal jeg med det nå?» Mannens kurs ble brått endret, og livet kunne ikke bli som før.

Et annet tilfelle jeg ikke kommer til å glemme, var en ung jente som brått mistet sin mor. Hun hang gråtende over moren sin og sa med redde øyne: «Nå er jeg alene». Kriser kan være svært dyptgripende.

Det er individuelt hvordan mennesker reagerer på og takler kriser (3). Her er det ingen fasit. Hvert individ har sin opplevelse av sin situasjon. Vi evner å sette oss inn i den andres situasjon til en viss grad, samtidig er det viktig å merke seg at vi aldri kan forstå et annet menneske fullt ut (7).

\section{Kriserammetes behov}

Mennesker i krise har behov for støtte, omsorg, medmenneskelig kontakt og noen å dele tanker og følelser med. Medmenneskelighet trekkes frem som det sentrale i krisehjelp (6). 
Krisehjelp er ikke behandling eller problemløsning, men hjelp til vekst. Vi må hjelpe individet gjennom krisen. Det handler ikke om hva vi som hjelpere gjør, men snarere om hva vi er - vi må møte mennesket der det befinner seg. Mange kjenner seg nok igjen i at vi ønsker å se resultater når vi anstrenger oss for noe, men slik er det ikke i møte med mennesker i krise.

Jeg som sykepleier har ingen løsning for den unge jenta som brått mistet sin mor, ei heller for ham med uhelbredelig kreftsykdom. Det er tøft å se andre mennesker ha det vondt, og det krever noe av oss å stå i slike situasjoner (10).

\section{Maktes|øsheten}

Maktesløsheten sitter av og til som en klump i magen og river i oss. Som sykepleiere opplever vi livet på kloss hold; det er virkeligheten som finner sted. For de fleste er nok motivasjonen for å jobbe i helsevesenet at vi vil hjelpe og utgjøre en forskjell. Da føles det naturlig nok vanskelig når vi som hjelpere ikke kan gjøre noe.

\section{三 «Som sykepleiere opplever vi livet på kloss hold; det er virkeligheten som finner sted.»}

Bent Falk setter søkelyset på maktesløsheten i boken sin $A$ være der du er. Han påpeker at vi som hjelpere ikke må gjøre maktesløsheten til et problem i tillegg til vanskelighetene vi står overfor. Da sitter vi plutselig med to problemer. Selv om emnet vi skal samtale om, er komplisert, trenger ikke samtalen om emnet være det (1).

Kanskje må vi gå i oss selv og kjenne etter. Opplevde vi møtet eller samtalen med den kriserammete som komplisert fordi vi følte oss rådville? Klarte vi ikke å stå i situasjonen og kjenne på at verken prosedyrer eller trøstende ord kunne lette den? Eller klarte vi ikke å bære smerten ved at andre hadde det tungt? 


\section{Ingen bagatell}

Jeg ønsker på ingen måte å bagatellisere at et møte eller en samtale med den kriserammete kan føles komplisert og vanskelig, for de er ofte veldig vanskelige. Slutter vi å bli berørt i møte med mennesker som har det forferdelig, er det nok på tide å stoppe opp og ta et oppgjør med seg selv.

Men påstanden om at det ikke trenger å være så komplisert, er kanskje en påminnelse om at vi må forholde oss til virkeligheten. Jeg tør å påstå at det kanskje blir litt lettere å møte mennesker i krise hvis vi aksepterer at vi som sykepleiere av og til ikke kan gjøre noe. For noen ganger handler det virkelig om ikke å gjøre noen ting, men stole på at det faktisk er nok å bare være der (5).

\section{Samtalen som verktøy}

Som sykepleiere har vi samtalen som verktøy, og dermed ønsker vi å kunne si noe til den kriserammete (1). I situasjoner der det ikke er mulighet for endring, der du ikke kan love en bedre fremtid, sier det seg selv at det blir vanskelig å trøste med ord (5).

Hva skulle jeg ha sagt til mannen som lykkelig hadde spart til hytte, men som nå snart skulle dø? «Det kommer til å gå bra? Du kan bruke pengene på noe annet?» Eller til jenta som mistet moren sin. «Med tiden kommer du over det»? Nei. Prøver vi her med trøstende ord, kan de fort bli tilgjorte og tomme (5). Så hva sier vi?

\section{三 «Som hjelpere kan vi være ærlige og si: ‘Nå vet jeg ikke hva jeg skal si.'»}

Som hjelpere kan vi være ærlige og si: «Nå vet jeg ikke hva jeg skal si.» Vi kan være til stede og stå til rådighet som det mennesket vi er. Vi kan vise respekt ved å dele det som skjer med oss i møtet med den kriserammete (1). 


\section{Vær ærlig}

Jeg har erfart at når jeg er ærlig og forteller at ordene mine blir fattige, så godtas det. På meg virker det som at den kriserammete opplever det som medmenneskelighet, og at de dermed blir møtt med respekt. Jeg er ikke et supermenneske som vet alt og kan svare på alt, og det blir helt feil om jeg skulle ha latt som.

Det er våre svake sider som er mest troverdige, og ærlighet virker tillitsskapende. Ved å avsløre egne begrensninger som hjelper, blir det lettere for den andre å leve med sine begrensninger (1).

Videre kan jeg spørre «er det noe du vil jeg skal si?», eller «nå vet jeg ikke hva jeg skal si, men hvis du vil, skal jeg sitte her sammen med deg». På denne måten er jeg ærlig samtidig som jeg viser medmenneskelighet og stiller meg selv til disposisjon.

\section{Kan si oss enige}

Ofte erfarer jeg at mennesker i krise uttrykker at de synes situasjonen er urettferdig eller helt forferdelig. Jeg har da kjent meg svar skyldig. Mannen som ble konfrontert med uhelbredelig kreft, utbrøt «det er helt jævlig!», og det var jo sant. Det var helt jævlig.

Men hva skulle jeg si? Er det greit at vi som sykepleiere sier oss enige i det? «Ja, det er helt jævlig.» Fører det til at vi fremhever mannens vanskelige situasjon, eller kan det fungere som en slags bekreftelse, at han føler seg sett, hørt og tatt på alvor? Eller skal jeg forsøke å dempe hans følelser ved å «trøste dem vekk»? 
Hvis to mennesker er sammen om noe som er vanskelig i livet, kan det bli lettere å hanskes med. Men hvis den ene avviser samtalepartnerens følelser, kan det skape avstand. Om følelsene samsvarer med virkeligheten slik vi oppfatter den, er det ikke følelsene som er problemet. Det er selve virkeligheten som er problemet (1).

Sett i et slikt lys kan vi kanskje si at det blir rett å si seg enig i mannens utsagn om at «det er jævlig». Virkeligheten dreier seg om at han har fått kreft og snart skal forlate livet. Det sier seg selv at vi ikke kan eller bør trøste bort hans oppfatning av sin egen situasjon.

\section{Hva skal vi ikke si?}

Det å se virkeligheten i øynene kan bidra til mestring og føre til at pasientene sparer psykisk energi på å slippe å fortrenge følelser (1).

Innledningsvis var jeg inne på frykten for å si noe som kan gjøre det verre. Er det noe vi absolutt ikke skal si? Blant mine kollegaer sier vi ofte at vi ikke kan si så mye feil, så lenge vi trår varsomt og viser respekt.

I litteraturen dukker det opp enkelte utsagn som oppleves som uvørne bemerkelser, som for eksempel «sorgen vil forsvinne med tiden» og «det er en mening med alt» (9). Jeg mener at dette er klassiske eksempler på at trøstende ord fort kan bli tilgjorte og virke tomme, selv om ordene nok ble sagt i beste mening (5).

\section{$\equiv$ «Av og til er det kanskje best å ikke si noe.»}

Av og til er det kanskje best å ikke si noe. Det er i hvert fall det vi pleier å konkludere med på sengeposten der jeg jobber.

\section{Å kjenne på taushet}


Det å tørre å kjenne på taushet kan være vanskelig. Det er anstrengende å holde igjen egne ord (5). Jeg sitter ofte sammen med pårørende idet en av deres nære ligger på det siste. Jeg er også ofte sammen med dem som har fått verden slik de kjente den, snudd på hodet. Det er stille - ingen sier noe. Følelsen av at jeg som sykepleier burde si noe klokt, melder seg i slike situasjoner, men jeg lar det være.

På samme måte som vi kan bruke mange ord på å si ingenting, kan vi si mye ved ikke å si noe (8). Det er mulig å dele kunnskap uten at den trenger å uttales (5). Stillhet har blitt til et verktøy jeg bruker ofte. Her har jeg erfart at min tilstedeværelse betyr alt, for taushet kan også oppfattes som om vi er uinteresserte eller fraværende.

\section{Være stille sammen}

Vi må være stille sammen med den som er i krise. Alle gode ord i universet kunne ikke trøstet jenta som brått hadde mistet moren sin. Taushet kan gjenspeile vennlighet og respekt (8), og sammen med jenta valgte jeg å prate med kroppen og øynene. Vi sitter sammen og tenker over det som før har blitt sagt.

Jeg har opplevd at det føltes fint å sitte stille sammen, og at den kriserammete selv har påpekt at «det var så godt du bare var der, uten å si noe». Etter at jeg har sittet i taushet sammen med noen en stund, kan praten ofte komme forsiktig tilbake, og da er det som om det ikke har vært stille.

Andre ganger er det nok med en god hånd på skulderen og et trygt og vennlig blikk som sier «jeg er her med deg». På denne måten viser vi medmenneskelighet.

\section{Når tårene kommer}


Det å møte medmennesker som står oppe i eller har gjennomgått noe forferdelig, beveger oss som hjelpere og kan vekke alle slags følelser. Noe fordi det er allmennmenneskelig, annet fordi det kan relateres til egne personlige erfaringer.

Når vi blir beveget av andre, viser vi at vi er åpne for den personen og vedkommendes liv, samtidig som vi er i kontakt med oss selv. Med vårt nærvær og oppmerksomhet er det her vi som hjelpere gir det beste av oss selv (10).

Haakon Wiig (11) deler åpent og ærlig sine erfaringer om det å være pårørende i artikkelen «Den vanskelige samtalen». I ti år fulgte han sin kone inn og ut av sykehus til hun døde av kreftsykdom. Artikkelen er en appell til sykepleiere som støttet ham og hans kone i den vanskelige tiden.

Han trekker blant annet frem at vi som sykepleiere har lov til å vise følelser, og at nettopp det var noe han satte stor pris på. Om en tåre faller, eller om stemmen blir svak, er det helt greit. Wiig ser på det som et bevis på profesjonalitet.

Det hender jeg får tårer i øynene, og enkelte ganger renner noen tårer nedover kinnet. Jeg tørker dem stille og rolig bort. Jeg har undret meg over om det er greit å gråte.

Wiig (11) er inne på at sykepleierne han møtte, alltid var profesjonelle i den forstand at de beholdt roen og aldri endte opp i ukontrollert gråt. Forholdet mellom hjelper og den som trenger hjelp, må ikke bli snudd på hodet. Den som er i krise, skal ikke være nødt til å trøste oss som er sykepleiere.

Tidligere i artikkelen oppfordret jeg til å dele det som skjer med oss i møte med mennesker i krise. Vi kan være ærlige og si «nå ble jeg rørt» eller «historien din beveger meg». 
På den andre siden kan vi velge å holde igjen våre egne ord, og likevel si mye uten ord. Samtidig aksepterer vi maktesløsheten og stoler på at det er nok å bare være der. På denne måten tror jeg at vi som sykepleiere evner å møte mennesker i krise som medmennesker.

\section{Referanser}

1. Falk B. Å være der du er - samtale med kriserammete. Bergen: Fagbokforlaget; 1999.

2. Malt UF. Lærebok i psykiatri. 3. utg. Oslo: Gyldendal Akademisk; 2012.

3. Helsekompetansesenteret. «Stø kurs». Tilgjengelig fra: http://kurs.helsekompetanse.no/traumebehandling (nedlastet 20.03.2017).

4. Hummelvoll JK. Helt - ikke stykkevis og delt. Psykiatrisk sykepleie og psykisk helse. 7. utg. Oslo: Gyldendal Norsk Forlag; 2012.

5. Bjørklund L. Tid til trøst - om de vanskelige møtene. Bergen: Fagbokforlaget; 2005.

6. Eide H, Eide T. Kommunikasjon i relasjoner. Samhandling, konfliktløsning, etikk. 2. utg. Oslo: Gyldendal Akademisk; 2007.

7. Carlenius S. Omsorg ved livets slutt. Møter med pasienter og pårørende. Bergen: Fagbokforlaget; 2008.

8. Herset I, Horverak S. Rom for taushet i profesjonelle samtaler. Bergen: Fagbokforlaget; 2011.

9. Dyregrov K, Dyregrov A. Sosial nettverksstøtte ved brå død. Hvordan kan vi hjelpe? Bergen:

Fagbokforlaget; 2007.

10. Bang S. Rørt, rammet og rystet - faglig vekst gjennom veiledning. Oslo: Gyldendal Norsk Forlag; 2003. 
11. Wiig H. Den vanskelige samtalen. Oslo:

Sykepleien; 6/2017. Tilgjengelig fra:

https://sykepleien.no/meninger/innspill/2017/04/den-

vanskelige-samtalen (nedlastet 05.07.2017). 